\title{
CONTENT PROVISION ON THE WEB: AN ECONOMIC CHALLENGE FOR TV STATIONS
}

\author{
Claudia Loebbecke \\ Erasmus University \\ Rotterdam School of Management \\ 50 Burg. Oudlaan. NL- 3000 DR Rotterdam \\ cloebbecke@fac.fbk.eur.nl
}

\begin{abstract}
Increasingly. TV stations are introducing online services as they seem to hold economic potential and open new markets. Nevertheless, networks have apparently until now been neglecting a careful evaluation of online services' strategic and economic potentials, which ultimately is a prerequisite to develop these markets and thus to profit from them.

Objective of this paper is to analyse some exemplary TV online services offered by the Globo TV network, the largest television network in Brazil, as well as to assess their strategic potential and their economic benefit.
\end{abstract}

\section{KEY WORDS}

Content provision, Online services, Strategic potential, Cost-benefit analysis, Brazil

\section{INTRODUCTION}

The increase in the private and commercial use of the Internet has encouraged a large number of companies in different business sectors to conduct business over the Internet and to offer their own content and services on the Web. While some of the Internet-active companies follow well-prepared business plans regarding their online activities, others have just got started. Similarly, while numerous companies gained remarkable benefits from their Internet activities (Benjamin, Wigand 1995; Angell, Heslop 1995; Jones 1994), others are learning their lessons 'the hard way' (Loebbecke 1996; Riefer 1996). Therefore, an in-depth analysis of the economic contribution and the strategic potential of online services is of importance: competitive opportunity, competitive necessity, or just 'nice-to-have'?

The recent rush to establish an Internet presence has also been followed by TV stations. Private and public stations are either already using the Internet or they are starting to build up an online presence. The strategic potential of TV online services is particularly interesting, there is a high growth potential as currently about ten to twelve percent of European households have access to the Internet, while almost 100 percent have access to public TV (e.g. Media Perspektiven 1995).

Three developments in the TV sector lead TV stations to investigate the strategic potential and the economic performance of their recently introduced or upcoming online services.

(1) For about fifteen years, private TV stations have been allowed to enter the markets in their home countries (Meffert, Hensmann 1993).

(2) With the diffusion of cable TV and the increasing popularity of satellite TV, end consumers can watch programs on TV channels of 'foreign' TV stations. Thus, the number of available and accessible TV stations has increased continuously.

(3) This increase in 'accessible' TV stations has been accompanied by a rise in the number of broadcasted channels per station. With the development of digital technologies, TV stations start to broadcast several channels (niche programs).

To tackle this growing competitiveness, TV stations are increasingly introducing TV online services, as they seem to hold economic potential and open new markets. Nevertheless, networks have apparently until now been neglecting a careful evaluation of online services' strategic and economic potentials, which ultimately is a prerequisite to develop these markets and thus to profit from them.

Objective of this paper is to analyse some exemplary TV online services offered by the Brazilian Globo TV network as well as to assess their embedded economic challenge as well as their strategic and economic potential.

\section{FRAMEWORK FOR INVESTIGATION}

Following general economic potentials of content provision on the Web (see Loebbecke 1996), TV Online Services may contribute to a TV network's revenue in four ways (see Figure 1): 


\section{General}

- Increased number of products sold due to Internet-based marketing

- PR

- Product information

- Larger margin due to

- Lower internal cost (efficiency)

- Higher prices based on value added for the customer

- Content offered on the Internet as additional product line

- Space on web pages offered as additional source of income I product line

\section{TV stations}

- Increased share of viewership / advertising time sold due to Internet activities

- PR (---> TV station)

- Show, news, sports information

- Larger margin due to

- Lower cost for mailings / internal communication, etc.

- Higher prices (for advertising) based on value added for the customer

- Content offered on the Internet as additional product line

- Space on web pages offered as additional source of income / product line

Figure 1: Economic potential of content provision on the Web

(1) Online services optimise business processes and therefore contribute to cost reductions (efficiency). TV stations could reduce costs by using the Internet as an internal communication tool and for efficient communication with viewers.

(2) Online services increase either the number of units sold or the price that can be charged per unit. TV online services could increase the share of audience of particular programs and consequently lead to a higher advertising income on the TV advertising market by having more advertising minutes sold or by charging higher prices for a given number of minutes.

(3) Advertising facilities on web pages offered to third parties represent an additional source for income.

(4) Consumers pay directly for specific online services which thus turn into stand-alone products sold separately in the market.

This paper aims primarily at assessing the strategic potential of TV online services for keeping current and gaining new customers. Therefore, issue (1) - efficiency of internal processes - is not investigated further, as is issue (4) due to the lacking application of secure payment systems on the Internet.

Though conceptually different, issues (2) and (3) for TV stations can be considered together. For private TV stations, advertising income is the major revenue source and the analysis focuses on the online-driven increase in advertising income resulting either from an increase in audience share (program-specific advertising income) or from a greater number of hits on web pages (Internet-specific advertising income).

Figure 2 depicts the media-interdependence with regard to advertising income and thus economic potential of TV online services (see also Loebbecke, Powell, Trilling 1998). There is an obvious link between audience share and program-specific advertising, as the price of advertising time is determined by the number of viewers. Web-based online services that can attract additional viewers on the one hand, and television programs which encourage viewers to make use of online-services on the other, are connected in a reciprocal or even complementary way. Lastly, the price of an advertisement placed on a Web page is linked to the number of hits, as they are usually used as an indicator for the reach of the advertisement (Loebbecke, Powell 1997). 


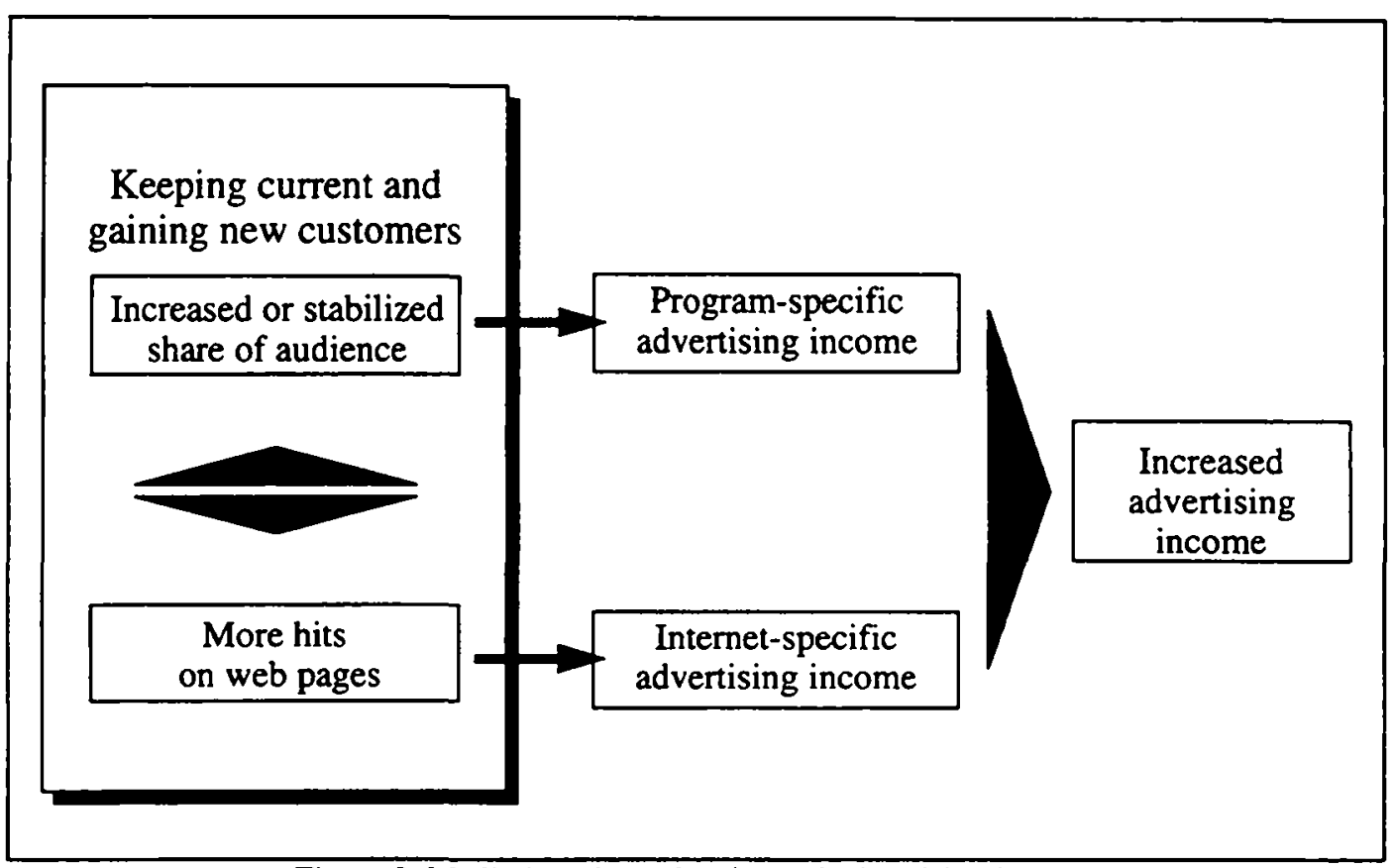

Figure 2: Media-interdependencies and advertising income

(Source: Loebbecke, Powell,Trilling 1998)

As a basis for further detailed investigation and comparison of TV online services Loebbecke and Powell (1997) suggest an 'Online Success per Program Typology' (OSPT) integrating (1) different kinds of programs, (2) success factors and (3) different kinds of TV online services (see Figure 3).

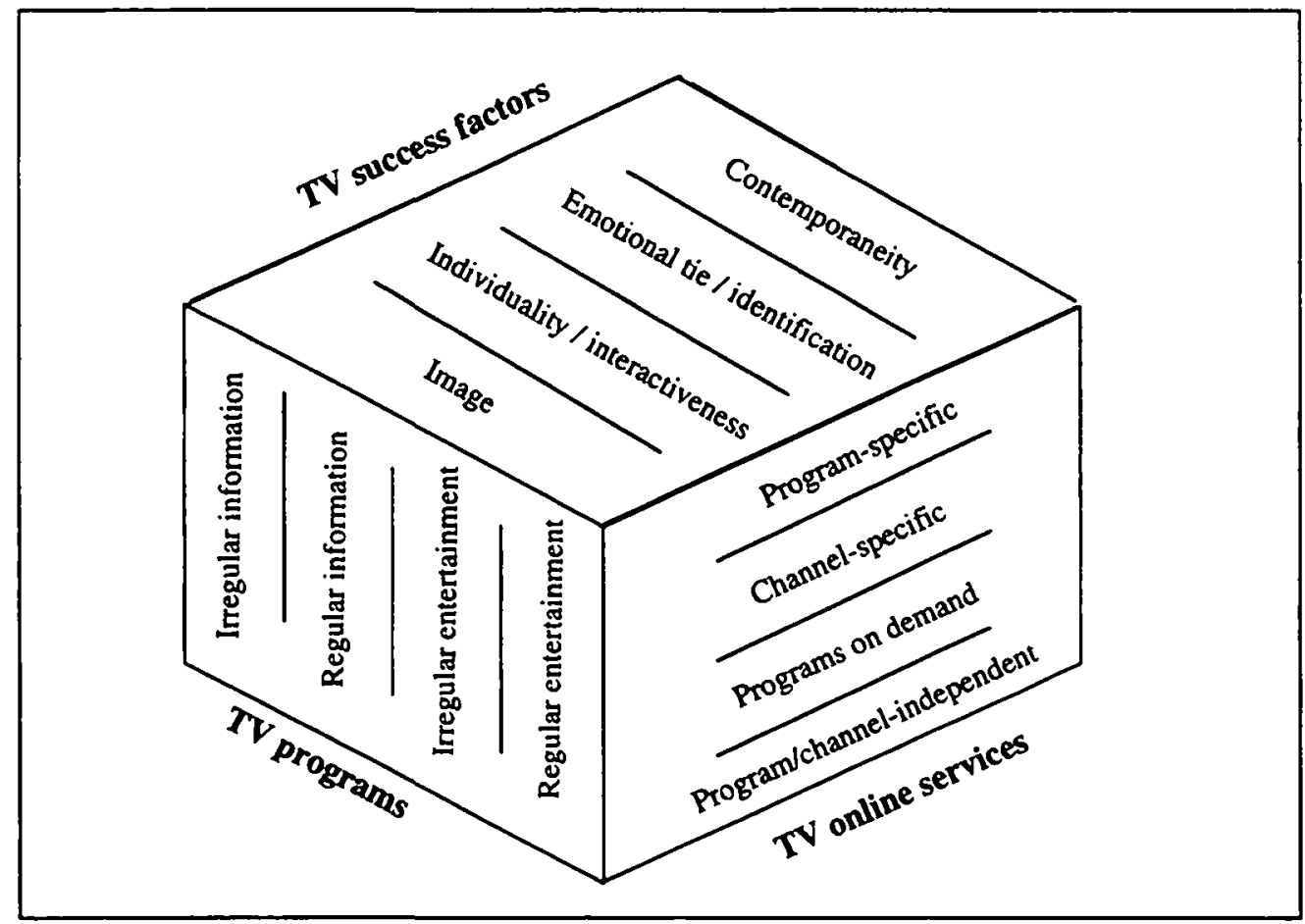

Figure 3: 'Online Success per Program Typology' (OSPT)

TV programs are distinguished according to the two dimensions contents (entertainment and information) (Krueger 1995) and emission regularity (once/irregular and repeated/regular).

The four identified success factors contemporaneity, emotional tie, individuality/interactiveness and image are used to analyse qualitative factors that cause the different levels of audience (Toffler 1980; Ishikawa, Muramatsu 1991; Mudie, Cottam 1991; Albers 1992; Greenberg, Busselle 1992; Collins 1993; Leggatt 1993; Schenk, Gralla 1993; Gleich, Groebel 1994; Duvinage 1996; Weise 1996). Contemporaneity is especially important for information programs and mainly depends on up-to-dateness of information and its availability to 
viewers. The emotional tie encompasses the viewer identification and the ability of the network, program or actor to influence him; it is a form of viewer commitment. This is a vital element for regular programs such as news or soap operas and can be based on content or people. Individuality and interactiveness, as a function of customer integration, are important for the perceived quality of services. The factor image is of significance for the competitiveness of the network and for the success of a particular program.

Table 1 summarises the four success factors and shows their importance for the different types of TV programs based on in-depth interviews in Germany, France, and the Netherlands.

\begin{tabular}{|c|c|c|c|c|c|}
\hline TV succe & Program type & $\begin{array}{l}\text { Regular } \\
\text { enter- } \\
\text { tainment }\end{array}$ & $\begin{array}{l}\text { Irregular } \\
\text { enter- } \\
\text { tainment }\end{array}$ & $\begin{array}{c}\text { Regular } \\
\text { infor- } \\
\text { mation }\end{array}$ & $\begin{array}{c}\text { Irregular } \\
\text { infor- } \\
\text { mation } \\
\end{array}$ \\
\hline & $\begin{array}{l}\text { Contempo- } \\
\text { raneity }\end{array}$ & - & - & ++ & ++ \\
\hline $\begin{array}{l}\text { Program } \\
\text {-specific }\end{array}$ & $\begin{array}{l}\text { Emotional tie } \\
\text { and viewer } \\
\text { identification }\end{array}$ & ++ & + & ++ . & + \\
\hline & $\begin{array}{l}\text { Individuality } \\
\text { and inter- } \\
\text { activeness }\end{array}$ & ++ & ++ & ++ & ++ \\
\hline $\begin{array}{l}\text { Non- } \\
\text { program } \\
\text {-specific }\end{array}$ & Image & + & + & + & + \\
\hline
\end{tabular}

++ very important + important - not important

Table 1: TV success factors and their relevance for program types

(Source: Loebbecke, Powell, Trilling 1998)

Concerning TV online services, the approach integrates 'supportive' versus 'stand-alone' online services (Alpar 1996) and the focus on the 'unit covered' (Schroeter, Ewald 1996), e.g., station, channel, and program differentiates four main kinds of TV online service (Loebbecke, Powell, Trilling 1998):

(1) Program-specific online services concern particular TV programs and may be further classified according to their interactiveness. If viewers desire information, the 'interaction' only consists of clicking on web pages (passive Internet use). However, online services may also encourage viewers to express opinions (active use).

(2) Channel-specific, but program-independent online services, assist consumers to familiarise themselves with the TV station.

(3) Stations can place segments or entire programs on the web. Such 'programs on demand' not only provide the opportunity to view contents individually, but also facilitate the acquisition of viewers who cannot access conventional transmissions (e.g. those living abroad).

(4) TV stations increasingly offer channel and program-independent online services, e.g., information services, online games, to enlarge their business scope.

\section{THE CASE OF REDE GLOBO ${ }^{20}$}

In the following two sections, we will introduce Brazil's Red Globo TV network, the largest television network in Brazil, and apply the proposed framework to analyse some exemplary TV online services as well as to assess their strategic potential and their economic benefit.

\section{Case setting: Brazil and the Brazilian telecommunications and television industry}

\section{Demographic and economic particularities of Brazil}

Brazil is the fifth largest country by area in the world and the only state in South America where Portuguese is spoken. There is a very sharp division in society between the rich and the poor. Only about $60 \%$ of the 162.6 million population dispose of any buying power beyond their most basic needs. A concentration of economic wealth lies along the coast, especially in the southern part (Economist 1995; Baratta 1996; CIA 1997).

Brazil is the world's eighth largest economy with an estimated GDP at purchasing power parity of US $\$ 976.8$ billion in 1995 (CIA 1997). Until 1990, Brazil was a relatively closed economy, but then adopted an aggressive liberalization strategy which immensely increased the competitiveness of most sectors. Efforts were made to

20 An earlier version of the Red Globo case and its analysis appeared in [BUTZBACH, LOEBBECKE 1998]. 
privatise state-owned monopolies. This led to dramatic changes in technology, especially telecommunications (Economist 1995, KPMG 1996, UN 1996, BNDES 1997).

Brazil has a very young demographic structure. Table 2 shows the estimate for July 1996; life expectancy at birth is 61.62 years (CIA 1997). A high degree of illiteracy is still a major problem with only an estimated $83.3 \%$ (1995) of the population at age 15 and over being able to read (CIA 1997).

\begin{tabular}{|lr|}
\hline Age & Share of population \\
\hline $0-14$ years & $31 \%$ \\
$15-64$ years & $65 \%$ \\
65 years and over & $4 \%$ \\
\hline
\end{tabular}

Table 2: Age structure in Brazil (estimate for July 1996)

\section{Brazilian telecommunications and television industry}

Brazil's telecommunications industry is controlled by formerly state-owned companies that have just recently been privatised. In the 1980's, most of the necessary investments were not carried through as the capital was used by the government to pay for the nation's debt instead of developing and maintaining the telecommunications infrastructure. As a consequence, the provision of telephone lines is a severe problem (Economist 1995; Pinhanez 1995; Gouvea Neto 1997). Nevertheless, the existing telephone net is in a good state. In 1994, there were an estimated 8.1 lines per 100 inhabitants compared to, for instance, 60.2 per 100 inhabitants in the United States (UN 1996).

Brazil is a country with one of the highest daily per-capita television consumption world-wide. Daily TV audience in Brazil's economic centers (São Paulo and Rio de Janeiro) in 1996 was 420 minutes (Paoletti 1996) compared to 241 minutes in the United States, 251 minutes in Japan and 196 minutes in Europe (Baldauf 1996). An estimated $82 \%$ of Brazilian households had television (corresponding to 32.65 million television sets) as per December 1993 (Paoletti 1996; UN 1996). There are currently around 4 million personal computers installed (Santos 1996; Marins 1996b).

Television industry is mainly financed by revenues from advertising (Wilke 1992). The estimated number of Internet users in Brazil was at 600,000 for November 1996 (Godoy 1996). The average net user pays roughly US\$30 per month for the basic service. This limits Internet usage to persons with a fair amount of buying power (Marins 1996a).

\section{Company overview}

Rede Globo is the television network of the Globo media giant, a company of great domestic influence and importance in Brazil (Wilke 1992; Gouvea Neto 1997). The conglomerate also holds print media, record labels (to commercialize Globo's soap opera soundtracks) and radio stations. In the last decades, it has been following an aggressive national and international expansion strategy. As a consequence, Globo TV has turned into a global player in a sophisticated and fast-moving high-technology sector which is becoming increasingly competitive. Being the fourth largest private television network in the world and one of the largest in-house producers of television programs, Globo TV is highly involved in the globalization of television and program distribution (Grosse-Kracht 1992; Netz 1996; Paoletti 1996; Gouvea Neto 1997; Rede Globo 1997). Globo is currently trying to position itself as the technology leader in the Brazilian and Latin American television markets, preparing to exploit new potential markets, products and services (Netz 1996; Salamanca 1996; Paoletti 1996; Gouvea Neto 1997; Rede Globo 1997). Rede Globo's audience share in Brazil is approximately as follows:

\begin{tabular}{|lc|}
\hline Time of Day & Share of Total Viewers \\
\hline Morning & $56 \%$ \\
Afternoon & $59 \%$ \\
Evening (prime-time) & $74 \%$ \\
Late-night & $69 \%$ \\
\hline
\end{tabular}

Table 3: Rede Globo audience shares

(Source: Gouvea Neto 1997; Rede Globo 1997)

Rede Globo has been following a strategy of technology leadership, launching new products and introducing new technology at a high pace and with a long-term approach. An emphasis lies on state-of-the-art equipment. This led to an environment which quickly adopted new developments and technologies (Herz 1987; GrosseKracht 1992; Wilke 1992; Gouvea Neto 1997; Rede Globo 1997). Almost all of Brazil (99.84\%) is covered by 
the Rede Globo television network with 107 broadcasting and affiliate stations. As a consequence of its national approach, it has traditionally had the biggest market share of Brazil's advertising budgets for television (65\%) as shown in Figure 4.

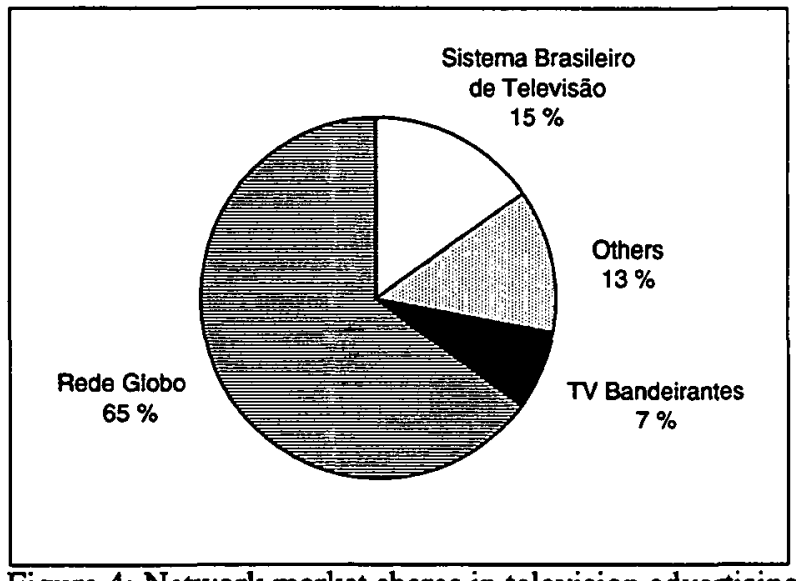

Figure 4: Network market shares in television advertising

(Source: Gouvea Neto 1997)

\section{Rede Globo's online services}

Rede Globo's Web-based online services (http://www.redeglobo.com.br) started in 1996. As of November 1997, there were no commercial or non-Globo advertisements.

\section{Television program schedule}

On this page, the daily television program times are shown. Some of the programs offer hyperlinks to the individual home page of that program. There is the possibility to retrieve the schedule for the remaining days of the week and for the following week.

\section{Additional information on programs}

This is a platform to access the content offered by the individual programs, such as science and news programs, soap operas, etc. For instance, for these soaps the TV online services provide an introduction to the story, the plot, information about the author and the director as well as a presentation of the production team, the cast and the technical staff. Besides Portuguese, some of the pages also offer the content that does not change on a daily basis, in English and Spanish. Most of the pages also allow for feedback via a dedicated e-mail-address hyperlink.

\section{E-mail contact}

This page allows viewers to contact the makers of the most popular programs via e-mail by clicking on icons with the program-specific logos, letting them recognise their program visually rather than in text form.

\section{Company information and sales}

By choosing this link, interested parties can obtain company information (in Portuguese, English and Spanish) as well as information on in-house productions currently for sale (in English and Spanish). Besides the plots of the production, the names and full addresses of the sales representatives are supplied. Also available is information on merchandising possibilities for soap operas.

\section{News from the recording sets}

Behind this link, viewers can obtain the latest news from the recording sets. This includes information on what is currently being recorded, small and big problems at the studios, updates on stories, and gossip about the actors. 


\section{Planned expansion of Red Globo's online services}

Rede Globo is planning to expand its online services to increase the benefits created. Online services are to be used to lower the cost of interaction. For example, instead of reading, processing, printing and mailing replies to viewer letters, e-mails will be processed and suggestions for replies made automatically before being sent via the Internet. This will not only save the postage and handling, but also reduce human processing time to a minimum. The Internet will then substitute part of the amount of telephone calls on toll free lines (Antunes 1997).

The offering of additional information will be enlarged in the near future and is being implemented for breaking news headlines and Brazilian economic news. Rede Globo already uses its pages to supply company information and present its efforts in charity and welfare programs. These online services are to be enlarged and it is planned to add links to charity programs encouraging viewers to (possibly online) support them (Antunes 1997).

Also, the usage of online services is planned to be more closely monitored to establish individual viewer profiles for certain social segments or age groups. A good example for the possibility of gathering quantitative data is the 'Angélica' page. A doll of the children's program presenter 'Angélica' can be dressed by the young viewers online from a selection of clothes. Besides being a fun activity, the information will be gathered and used to dress 'Angelica' according to the preferences of her viewers. The information will also be used for advertising purposes and trend research, as this social segment is the main addressee of non-basic consumer goods (Antunes 1997).

\section{ANALYSIS OF REDE GLOBO'S ONLINE SERVICES ACCORDING TO THE PROPOSED FRAMEWORK}

\section{Success factor importance per product category}

In the following analysis of examples from the Rede Globo online services, the classification of TV online services shown above will be used. The importance of the introduced success factors is assessed for each of the three categories. Program- and channel-independent online services are disregarded, as none are offered by Rede Globo.

\section{Program-specific online services}

The majority of the offered online services are program-specific. Examples for this are 'Jornal Nacional' (daily news program), 'Por Amor' (telenovela) and 'Angelica' (children's program with a live audience of elementary school-aged children) pages.

Contemporaneity is an important success factor for the 'Jornal Nacional'. The online offerings include discussions and background information on a selected number of subjects treated in the TV edition, but there is no separate and comprehensive online edition

Emotional tie and viewer identification are vital for 'Por Amor' and 'Angélica'. 'Por Amor' needs an emotionally involved audience to keep its share of audience which determines the amount and price of advertising. A drop in audience may even make it necessary to start a new soap. The 'Angélica' page tries to bind its young audience by offering them additional activities, pictures, music, video clips and a contest to increase the level of involvement.

Individuality and interactiveness are important for 'Por Amor' and 'Angélica', less for 'Jomal Nacional', as viewers have no influence on the happenings that constitute the news. 'Por Amor' is, as any soap, permanently in progress and each episode is written just ahead of recording. As the story develops and becomes more concrete, Rede Globo has to keep track of audience profiles, checking on their expectations to let the story run in that direction. The viewers become virtual co-writers of the soap-operas they watch and thus their personal preferences can be taken into account. Consequently, the interaction with them is vital for the program's success. This is achieved by offering the possibility to read previews of the episodes just ahead and to give e-mail feedback on the development.

Finally, image is a very important success factor for the online services of all of the three programs, but the conveyed image has to be different. Whereas 'Por Amor' must be up-to-date on social concerns and public opinion, 'Angelica' must be trendy and innovative. 'Jornal Nacional', on the contrary, should convey an image of a reliable and trustworthy supplier of information.

\section{Channel-specific, but program-independent online services}

Examples for channel-specific, but program-independent online services are 'Programaçāo' (TV program guide) and 'Institucional' (company information) pages. 
Of course, contemporaneity is of vital importance to the 'Programação' TV program guide. Viewers expect to see the valid version of the programming. Thus, any sudden changes in the schedule must be posted in this online service without delay. For the 'Institucional' company information pages, this is less important, as the history and development of the company can't change, only - and rarely - its perception.

Emotional tie and viewer identification as well as individuality and interactiveness have little importance for the 'Programação' and the 'Institucional' online services.

Lastly, image is the dominating factor for the 'Institucional' pages. These pages are used for public relations purposes and convey a positive, non-controversial view of the network. For 'Programação', image can only have a negative effect, if the program guide gives wrong information. Its potential to convey a positive image is very limited.

\section{Programs-on-demand}

No programs on demand are currently offered except for short clips on the 'Angélica' page which cannot really be considered as such.

Table 4 shows the relative impact of Rede Globo's program-specific and channel-specific TV online services on the different success factors. Program-specific service barely contribute to contemporaneity and individuality linteractiveness. Also less important are channel-specific services for emotional tie and viewer identification, as well as image. Channel-specific services promote contemporaneity, on the other hand, more than previous investigations in Europe had suggested.

\begin{tabular}{|l|l|cc|}
\hline \multicolumn{2}{|c|}{ Online service } & $\begin{array}{c}\text { Program- } \\
\text { specific }\end{array}$ & \multicolumn{1}{c|}{$\begin{array}{c}\text { Channel- } \\
\text { specific }\end{array}$} \\
\hline Program-specific success factor & $\begin{array}{l}\text { Contempo- } \\
\text { raneity } \\
\text { Emotional tie } \\
\text { and viewer } \\
\text { identification } \\
\text { Individuality and } \\
\text { interactiveness }\end{array}$ & ++ & ++ \\
\hline $\begin{array}{l}\text { Non program- } \\
\text { specific }\end{array}$ & $\begin{array}{l}\text { Image } \\
\text { +++ high impact } \\
\text { Table 4: Impact of TV online services on TV success factors }\end{array}$ \\
\hline
\end{tabular}

\section{Assessment of the strategic and economic impacts}

The assessment of the additional cost created through online services can only be estimated, no precise fugures are available. One time costs to set-up were around US\$ 250,000 , and minimum yearly maintenance costs are US $\$ 50,000$ (maintenance costs are an own estimate based on the necessary manpower of two full-time positions for current online services offering). The set-up includes procured hardware and software as well as installation and training costs (Antunes 1997).

On the positive side, according to Globo TV, there is limited direct return (direct additional revenues or savings) from its online services yet. The currently expected economic potential is a savings of up to $1.6 \%$ of total cost of toll-free telephone lines. Indirect revenue from online services-based marketing and a more positive image cannot be estimated, but seems to be rather limited due to the fact that the number of Internet users in Brazil is still very small in comparison to the total number of TV program viewers. Thus online services can only have a slight influence on increasing the number of viewers and in turn raising advertisement prices (Antunes 1997).

Nevertheless, Rede Globo tries to support a rapid expansion of Internet-usage by specifically addressing young viewers as target group. Investments in online services are seen as a further step in slowly developing this new potential and in conveying a technology leader image.

The company's technology leader approach makes it a strategic necessity to pursue any promising new technologies, at least in the perception of the public. If TV online services turn into a competitive necessity or if new markets open, Rede Globo needs to have the new technologies up and running. The current offering of online services allows the testing of reliability and the gaining of experience with a still limited user base. Due to the novelty of the services, a comprehensive cost-benefit-analysis is not yet possible. 


\section{CONCLUSION AND FURTHER RESEARCH}

In the case of Red Globo it seems likely that online services were implemented without a clear idea of the objectives pursued. A trend was followed - without a clear answer to the question of 'why?'.

Generally speaking, even though offered online services are constantly increasing in proficiency and user utility, they do not seem to be generating any direct additional income for 'their suppliers' yet, nor do they seem to actually be developing new markets and potentials. As in the case of Red Globo, there are often no precise figures on the cost of the necessary investments available. Apparently, companies lack a serious investment plan and do not define a minimum expected return on investment. The (seemingly) low cost of online activities is frequently regarded as a sufficient justification.

Consequently, two crucial questions for TV stations considering the launch of TV online services should be answered before entering online activities:

(1) Is a positive return on investment to be expected?

(2) Are TV online services considered a competitive necessity for the station's core business?

If at least one of these questions can be affirmed, the set-up of online services is to be recommended. Otherwise, TV stations should at first refrain from doing so.

A positive answer to at least one of the two questions seems likely if content provision on the Web, and TV online services in particular, are embedded in a comprehensive business strategy and business model that explicitly takes into account the opportunities of innovative technologies. If, however, chances are sought only along traditional operational processes and lines of business, content provision might be economically risky.

The case of TV stations is quite obvious. Red Globo and other stations offer a wide variety and significant depth of content on their Web pages. Currently those pages are attractive and well taken, but do not generate income. However, the obvious demand for the content provided should allow for business models that lets TV stations and other content providers benefit from their extra performance: Possible solutions may include income generation via relevant additional advertising income on Web pages or directly charging consumers for the content and the convenient delivery (see issues (3) and (4) in Figure 1).

Only if none of the two options is seriously pursued, in the long run TV online service may turn into a competitive necessity that mainly reduces the available profit margin - an extra service expected by customers for free.

What developments can be expected in the near future? The general globalization tendency is a factor that will foster the development of TV online services. TV stations will be able to reach out to new viewers via the Web. This will open the door to a more global advertising market, but will also increase competition. Improvements in the infrastructure will lead to a higher interest in programs-on-demand via the Web. As can be concluded from the current boom in Pay-TV demand (in Brazil, for instance, the growth rate of Pay TV was 212\% between 1992 and 1996 and generated revenues of more than US\$ 1 billion in 1996), TV online services such as programs-ondemand have a particular potential in a country with a high degree of street violence. TV online services will probably follow this trend, but due to higher up-front cost for users (investments in PC or Web computer, telephone line, Internet provider, etc.) the development will be much slower.

The proposed framework and the presented case study raise several questions for further empirical and theoretical research: What insights gain be gained from applying the framework to a larger number of TV stations and other content providers such as newspapers, radio stations, or even very enterprises in different business sectors such as travel agencies or financial services? What are opportunities and limits for interorganisational comparisons or cross-sector analyses? Should the given classifications be further divided (complexity versus feasibility)? What other culture-specific factors play a role in different environments? Is there a correlation between online usage and the share of audience and how can it be measured? On a more general level: Is there a correlation between 'online usage' and the 'number of units sold' or the 'price per unit sold', and how can it be measured? Last, but not least, how could the framework be transformed into a business planning tool for content providers on the Web? Answers to these and other questions will provide valuable insights into a challenging area of business.

\section{REFERENCES}

Albers, R. (1992). Quality in television from the perspective of the professional program maker. Studies of Broadcasting, 28, 7-20.

Alpar, P. (1996). Kommerzielle Nutzung des Internet. Berlin.

Angell, D.; Heslop, B. (1995). The Internet Business Companion, Growing your Business in the Electronic Age. Cambridge, Massachusetts.

Antunes, R. (1997). Member online services team. Interview on August 6 in São Paulo, Brazil.

Baldauf, S. (1996). Briten sind Europameister im TV-Konsum. Tendenz 4, 30-33.

Banco Nacional de Desenvolvimento Econômico e Social (BNDES) (1997). The Brazilian Privatization Program. http://www.bndes.gov.br. 
Baratta, M.v. (ed.) (1996). Der Fischer Weltalmanach 1997, Frankfurt, Germany.

Benjamin, R.; Wigand, R. (1995). Electronic markets and virtual value chains on the Information Superhighway. Sloan Management Review, 36, 62-72.

Central Intelligence Agency (CIA) (1997). Worldfactbook. http://www.odci. gov/cia/publications/nsolo/factbook/br.htm.

Collins, A. (1993). Intellectuals, power and quality television. Cultural Studies 7, 1/93, $28-45$.

Duvinage, M. (1996). WDR, Head of 'Online Service Center'. Interview on Oct. 30 in Cologne, Germany.

Economist (1995). Survey Brazil - A glass half full. 7912(335) 74.

Gleich, U.; Groebel, J. (1994). ARD-Forschungsdienst - Beurteilung der Programmqualität im Fernsehen. Media Perspektiven, 5/94, 253-258.

Gouvea Neto, R. de (1997). Case Study: TV Globo - The Brazilian Media Giant. The International Executive, 2(39), 255-269.

Godoy, N. (1996). Com a porta na cara. ISTOÉ. http://www.zaz.com.br/istoe/ ciencia/141725.htm.

Greenberg, B.; Busselle, R. (1992). Television quality from the audience perspective. Studies of Broadcasting, 28, 157-194.

Grosse-Kracht, H.-J. (1992). Joint-venture und militärische Protektion - Zur Entstehungsgeschichte des brasilianischen Fernsehsenders TV Globo. Rundfunk und Fernsehen, 2(40), 247-256.

Herz, D. (1987). A Historia Secreta da Rede Globo, Porto Alegre.

Ishikawa, S.; Muramatsu, Y. (1991). The assessment of quality in broadcasting: research in Japan. Studies of Broadcasting, 27, 7-20.

Jones, R. (1994). Digital's World-Wide Web Server. A case Study. Computer Networks \& ISDN Systems, 272, November, 197-206.

KPMG (1996). Investment in Brazil. São Paulo.

Krueger, U.M. (1995). Trends im Informationsangebot des Fernsehens. Programmanalyse 1994 von ARD, ZDF, RTL, SAT.1 und Pro Sieben. Media Perspektiven 2(95), 66-78.

Leggatt, T. (1993). Quality in television: the views of professionals. Studies of Broadcasting, 29, 37-70.

Loebbecke, C.; Powell, P.; Trilling, S. (1998). Investigating the Worth of Internet Advertising, International Journal of Information Management, forthcoming.

Loebbecke, C.; Powell, P. (1997). Understanding Internet Advertising. International Conference of Information Systems (ICIS).

Loebbecke, C. (1996). Content Providers benefiting from the Internet. Fourth Strategic Information Systems Network (SISnet) Conference, Lisbon, Portugal.

Marins, M. (1996a). Net dumb no more, Brazzil. http://www.brazzil.com/p22sep96.htm.

Marins, M. (1996b). Reborn on the Web, Brazzil. http://www.brazzil.com/ p20apr96.htm.

Media Perspektiven (ed.) (1995). Basisdaten, Frankfurt, Germany.

Meffert, H.; Hensmann, J. (1993). Die Entwicklungsdynamik des europäischen Fernsehmarktes in den 90er Jahren. Vienna, Austria.

Mudie, P.; Cottam, A. (1993). The Management of Marketing Services. Oxford, UK.

Netz, C. (1996). A Globo Plim-Plim por Plim-Plim. Exame, http://www2.uol. com.br/exame/19empre1.html.

Paoletti, R. (1996). Fall Season for Globo, Brazzil. http://www.brazzil.com/ aug96.htm.

Pinhanez, C. (1995). Internet in developing countries: the case of Brazil. http://www.cea.mdx.ac.uk/CEA/Researchers96/clau/Internet_Br1.html.

Rede Globo (1997). Company Information. http://www.redeglobo.com.br/inst/ english/inst1.htm.

Riefer, K. (1996). Zeitungen online - Chance oder Risiko?. Media Perspektiven 10/96, 537-549.

Salamanca, D. (1996). Lateinamerika: Medienkonzerne unter sich. Media Perspektiven 12/96, 639-647.

Santos, A. (1996). Personal computers are hot. IEEE Spectrum 7(33), 34-39.

Schenk, M.; Gralla, S. (1993). Qualitätsfernsehen aus der Sicht des Publikums. Media Perspektiven, 1/93, 8-15.

Schroeter, C.; Ewald, K. (1996). Onlineangebote von Rundfunkveranstaltern in Deutschland. Media Perspektiven, 9/96, 478-486.

Toffler, A. (1980). Die Zukunftschance. Munic, Germany.

United Nations Department for Economic and Social Information and Policy Analysis - Statistics Division (UN) (1996). Statistical Yearbook 1994, New York.

Weise, D. (RTL Manager 'Online'). Interview on Nov. 5 in Cologne, Germany.

Wilke, J. (1992). Massenmedien in Brasilien. Wilke, J. (ed.). Massenmedien in Lateinamerika, Frankfurt, Germany. 